\title{
Good Corporate Governance Structures: A Must for Family Businesses
}

\author{
Alfred Sarbah, Wen Xiao \\ School of Management \& Economics, University of Electronic Science \& Technology of China (UESTC), \\ Chengdu, China \\ Email: sarbah@yahoo.com, xiaowen@uestc.edu.cn
}

Received 17 December 2014; accepted 6 January 2015; published 16 January 2015

Copyright (C) 2015 by authors and Scientific Research Publishing Inc.

This work is licensed under the Creative Commons Attribution International License (CC BY). http://creativecommons.org/licenses/by/4.0/

c) (;) Open Access

\section{Abstract}

Corporate governance refers to the structures and processes for the direction and control of businesses and the relationships among the management, board of directors, controlling shareholders, minority shareholders and other stakeholders. Since good corporate governance contributes to sustainable economic development by enhancing the performance of companies, it is imperative that companies adopts good corporate governance structures to enable them grow. Family businesses are an often overlooked form of business ownership in today's world, yet they constitute a majority of the businesses. This means that families own a significant share of businesses and can influence important decisions in today's business world. However, according to Neubauer and Lank, until recently, the study of corporate governance in family business has been a largely neglected area of research [1]. As family businesses are an important component of every economy and play a critical role in promoting growth of a country's economy, as they grow, they face same challenges and pressures as any major corporation. To succeed, they must remain ahead of the competition, adopt good corporate governance practices and skillfully navigate through market changes. This paper is an empirical study from the current authors' previous work on the topic "Corporate Governances in Ghanaian Family Businesses: A Conceptual Framework" [2]. It examines the state of corporate governance environment and the nature of the governance system employed by family businesses using Ghanaian family businesses as a case study. The paper underlines why it is important for family businesses to adopt good corporate governance structures and attempts to understand the point of view from the subjects' perspective, due to the complex social situations that exist in the family businesses.

\section{Keywords}

Corporate Governance, Family Governance, Family Business 


\section{Introduction}

In any organization, corporate governance is one of the key factors that determine the health of the system and its ability to survive economic shocks. The health of the organization depends on the underlying soundness of its individual components and the connections between them. Good corporate governance therefore contributes to sustainable economic development by enhancing the performance of companies and increasing their access to outside capital.

Family businesses are one of the foundations of the world's business community. Their creation, growth and longevity are critical to the success of the global economy. Despite facing many of the same day-to-day management issues as publicly-owned companies, they must also manage many issues that are specific to their status in order to grow since global economy is built around family businesses. In the views of Pearl Initiative \& PricewaterhouseCoopers [3], many of the largest multinational corporations began as family businesses, and around $90 \%$ of the world's businesses can be defined as family businesses, both in developed, developing and emerging markets with the majority are small and medium-sized enterprises (SMEs), but some are very large companies.

According to Ward [4], family businesses, over the world, represent a prevalent and prominent form of enterprise in the economic and social landscape. Some researchers estimate that, today, family-owned businesses comprise over 95\% of all business establishments in the worldwide [5]. Studies in the United States, Canada, Europe, Australia, and Latin America suggest that family businesses account for the majority of the businesses and have a major impact on the growth of the national economies [6].

There are many distinguishing characteristics of what a family business is, and the single most obvious point of difference, of course, is the ownership structure, and while this tends to take the form of direct and total family control, some firms also have non-family shareholders and/or executives, and a stock market listing is quite common. The family ownership structure also leads to notable differences in corporate governance provisions. Companies operating within widely different cultural and social contexts needs a governance framework that reflects this, especially in relation to sensitive issues such as board structures and succession arrangements.

Since family businesses are among the most important contributors to wealth and employment creation in virtually every country of the world, their state of governance is a cause for concern. In their views, Neubauer \& Lank states that until recently, the study of corporate governance in family business has been a largely neglected area of research [1]. However, recently, investigations into the governance of family businesses have become more numerous as indicated by Fahed-Sreih [7]. Gompers et al. [8] have stated that the notion of corporate governance defines a combination of relationships among stakeholders, which mainly composed a company's management, its board and its shareholders to improve organizational efficiency and market competitiveness.

At the very basic, corporate governance is about ensuring that the concerns of a company's shareholders and stakeholders are taken into proper account, and all their interests balanced. Therefore, for family businesses to offer greater transparency to the principal stakeholders, corporate governance should be achieved through main corporate governance elements such as board supervision, auditing process and financial disclosure as well as institutional and societal arrangements. In view of this, the question of governance of family businesses has therefore catapulted to prominence in recent years and in each context the growth of interest stems from the sense that there has been a governance crisis [2]. In the special case of a family firm, a robust corporate governance framework can ensure a productive and sustainable relationship between the family shareholders and the executives managing the business, who may or may not be members of the family in their own right.

The literature on corporate governance indicates that approach to this issue are deeply influenced by the historical, political, industrial, social and cultural contexts of a country and this is supported by the assertions made by Hua et al. [9]. These contextual elements are relevant for efficient economic governance as they help in reducing the uncertainties associated with economic transactions. Under these contextual elements, corporate governance therefore varies across countries [10]. In the views of Carney and Gedajlovic [11], personalized and relational aspects govern corporate governance in the Asian business context, while arm's length rules are followed in the western corporate governance context.

The corporate governance literature affirms that corporate governance is one of the important factors influencing performance [8] [12]-[19]. There are many different features describing corporate governance system in each country. Differences regard, mainly, stage of economic development, country's legal tradition (common or civil law), the development of the stock market, capital and ownership structure and business practices.

Milgrom and Roberts [20] start with recognition that the organization matters and corporate governance mat- 
ters, and asserts that survival and prosperity of any organization depends on how to tackle the critical matter of coordination and motivation inside the organization. In recent years, academics and professionals have shown increasing interest in the study of corporate governance, which enhances our knowledge of how corporate governance influences firm's management, strategies and performance. Corporate governance can be defined as the system by which companies are directed and controlled [21]. So, it centers on the configuration of control mechanisms that attempts to limit problems arising from potential conflict of interest among the different participants in the firm, such as, managers, shareholders, employees, creditors, etc.

The primary objective is to determine whether family businesses need corporate governance system by using Ghana as a case study. The study will also seek to raise awareness and understanding of governance issues, trends and existing practices amongst family businesses and finally enable family businesses to benchmark their own business against others in the country and gain insight from how similar businesses address these issues

The study will therefore show that corporate governance allows businesses to prepare for their pending initial public offering. For example, in Ghana, early introduction of corporate governance would prepare a family business well enough-even before it gets listed under the provisional listing regime. The existence of a board will induce rapid growth strategies in the family business for rapid profits; this will at a point require the business going public for larger finances. This will complement efforts by the Ghana Stock Exchange to encourage listing of family businesses on the market. Thus the transition from a small to medium and finally large company will be smoothly aided by an effective corporate control system.

\section{Literature Review}

Today, the scope of family businesses has expanded to include some of the world's largest companies and their economic weight remains massive. In all markets, family-owned businesses form the bulk of the economy and in terms of numbers of individual enterprises they account for a significant proportion of GDP in their markets. Small and Medium Scale Enterprises (SMEs) in Ghana, which are mostly family businesses, have been noted to provide about $85 \%$ of manufacturing employment, contribute about $70 \%$ of Ghana's GDP and account for about 92\% of businesses in Ghana. Agbor and Quartey [22] describe them as efficient and prolific job creators, the seeds of big businesses and the fuel of national economic engines. According to Mullineux [23], even in the developed industrial economies, it is the small family businesses rather than the multinationals that are the largest employer of the workers.

\subsection{Family Business Defined}

It is well established that the global economy is built on the family firm. Many of the largest multinational corporations began as family firms, and around $90 \%$ of the world's businesses can be defined as family firms, both in developed and emerging markets. In the view of Peters [24], the question whether a firm is a family business or not, has been a matter of concern from the very beginning of family business research. Family businesses have been defined on the basis of different family characteristics [25], levels of family involvement [26] and others family businesses dimensions. Chua et al. [27] defines a business to be a family business which pursues a certain business vision held by a dominant alliance controlled by family members or a small number of families in a manner that it is sustainable over a period through family generations.

However, it must be stated here that a review of the literature reveals a long list of elements used by numerous authors to define what a family business is [5] [28]-[32]. In line with these definitions, Donnelly [33], however, defines a family business as a company that: "has been closely identified with at least two generations of a family, and when this link has had a mutual influence on company policy and on the interests and objectives of the family. Such a relationship is indicated when one or more of the following conditions exist:

a) Family relationship is a factor, among others, in determining management succession;

b) Wives or sons of present or former chief executives are on the board of directors;

c) The important institutional values of the firm are identified with a family, either in formal company publications or in the informal traditions of the organization;

d) The actions of a family member reflect on or are thought to reflect on the reputation of the enterprise, regardless of his formal connection to the management;

e) The relatives involved feel obligated to hold the company stock for more than purely financial reasons, especially when losses are involved; 
f) The position of the family member in the firm influences his standing in the family;

g) A family member must come to terms with his relationship to the enterprise in determining his own career."

We can therefore conclude that a family business is any type of business operation in which a group of relatives have controlling interest in the corporation. These types of businesses may range from a local mom and pop retail store to a commercial family farm and even for large corporations operating in multiple locations. In many instances, a family business is passed from one generation to the next, with children often training to enter the business at certain ages and take over various functions from their parents over time.

Donnelly's definition covers two interacting dimensions of the family business, i.e. the family and the business. The understanding here is that to function properly, a business family may benefit from effective family governance, while the business may benefit from corporate governance. The primary focus of this paper will be on corporate governance, but without neglecting family governance.

It must be also stated here that the literature continues to have difficulty constructing common shared criteria to distinguish family business from non-family business [32]. Although family businesses have been defined in several ways [34]-[36] from Donnelley to today's family business definitions [37], the term "family" remains in convergence from diverging definitions. The only differentiation people can make between a regular company and a family business is the term "family" [38].

At its most basic, corporate governance is about ensuring that the concerns of a company's shareholders and stakeholders are taken into proper account, and all their interests balanced. In the special case of a family firm, a robust corporate governance framework can ensure a productive and sustainable relationship between the family shareholders and the executives managing the business, who may or may not be members of the family in their own right. In all family businesses, the potential for conflicts increases, for this reason, corporate governance in family businesses should include processes, principles, structures and relationships that resolve (role) conflicts in order to help the family to realise their particular visions, goals and objectives [39]. The vision of the family directs the business so as to maximise the potential wealth of current and future generations of family members.

The justification for the emergence of the field of family business research lies in the assumption that family and non-family businesses are different. Recent empirical studies, such as one amongst S\&P 500 firms [40], show that businesses being under the influence of the founding families outperform their counterparts. Especially in terms of performance (such as size, growth, profitability, etc.), significant differences between family and non-family businesses could be identified [41]-[43].

Since there is no consensus of opinion about the concept of what family business is, we can find certain common elements in the definitions within the literature to conclude what they are. Behind many of those conceptualisations, there is, either implicitly or explicitly, the idea of family influence or control over a business, basically in two forms, ownership and management [1]. Consequently, the key to understanding the behaviour of these organizations lies in the interaction of the two different sub-systems, family and business, and its effect on the actions of all those involved.

It must be stated that, the uniqueness of family businesses are rooted in the fact that the intra-organizational relationships are based on family ties and the intention is that those ties will last [5]. So, what makes a family business unique is the influence of a family group on the ownership, governance, management and succession, as well as on objectives, strategies, firm structure and the way in which these are formulated, designed and implemented [27].

Family businesses are the leading form of business enterprises in the world [44] including the United States where eighty five percent of all businesses are family owned [45]. Family businesses have a prominent place in Asia. For instance, it is reported that family business account 99.9 percent of all businesses in the private sector in India [46]. Similarly, family businesses dominate the Ghanaian business environment and have been noted to provide about 85\% of manufacturing employment in Ghana [47] [48] and they also account for about 92 per cent of businesses in Ghana. Family businesses in Ghana have an important role to play in spurring economic growth given that they represent a vast portion of the businesses in the economy. The issue of their governance is of critical significance given the important role they play in the Ghanaian economy. Family businesses and small and medium scale enterprises have been noted to make major contributions to employment generation, GDP and reduction of poverty in Ghana [47] [49]. The lack of proper governance mechanisms may well cripple the effective development and growth of family businesses in Ghana and elsewhere. It is important then for proper management of this sector to ensure enhanced performance. A study of corporate governance issues in the Ghanaian family business sector is therefore a relevant research area. 
As family businesses expand from their entrepreneurial beginnings, they face unique performance and governance challenges. The generations that follow the founder, for example, may insist on running the company even though they are not suited for the job. And as the number of family shareholders increases exponentially generation by generation, with few actually working in the business, the commitment to carry on as owners cannot be taken for granted. To be successful as both the company and the family, a family business must meet two intertwined challenges: achieving strong business performance and keeping the family committed to be capable of carrying on as the owner. Five dimensions of activity must therefore work well and in synchrony:

a) Harmonious relations within the family and an understanding of how it should be involved with the business;

b) An ownership structure that provides sufficient capital for growth while allowing the family to control key parts of the business;

c) Strong governance of the company and a dynamic business Portfolio;

d) Professional management of the family's wealth;

e) Charitable foundations to promote family values across generations [50].

Today, the scope of family businesses has expanded to include some of the world's largest companies and their economic weight remains massive. In all markets, family businesses form the bulk of the economy and in terms of numbers of individual enterprises, they account for a significant proportion of GDP in their markets. Agbor and Quartey [22] describe them as efficient and prolific job creators, the seeds of big businesses and the fuel of national economic engines. Even in the developed industrial economies, it is the small family businesses rather than the multinationals that are the largest employer of workers [23]. It therefore becomes imperative for them to be governed well.

For the purposes of this study, a "family business" is defined as a business in which:

a) The majority of votes are held by the person who established or acquired the firm (or their spouses, parents, child, or child's direct heirs);

b) At least one representative of the family is involved in the management or administration of the firm;

c) In the case of a listed company, the person who established or acquired the firm (or their families) possess $25 \%$ of the right to vote through their share capital and there is at least one family member on the board of the company.

Family Businesses represent the highest proportion of businesses in the world [51]. When using the broadest definitions, 90-98\% of all businesses can be described as family businesses [52]. They are generally perceived as small, inward oriented and less professional companies compared to other business forms [53].

The increased liberalisation of trade has created a vast amount of new opportunities for businesses during the last decades, but also increased the demands for specialisation and shaped the way companies do business [54]. As a result of this, it became necessary for companies to engage on board in order to stay competitive [55]. One important issue in this field is corporate governance and especially how firms set up structures and policies within the growing company, to create a frame in order to direct and control the company’s activities [51].

\subsection{What Is Corporate Governance}

The issue of globalisation is offering new business opportunities, growth and diversification for family businesses, which are consequently becoming more complex organizations. Generally speaking, growth goes in hand with several aspects, which all require that family businesses have to adapt their governance system such as an increasing separation of ownership and management, the involvement of new generations within the company, or a growing number of non-family managers [56] [57]. As a result of this, ownership, control, ownership dilution and governance mechanisms that regulate separation of ownership and control have been increasingly acknowledged in research over the past two decades [58]. These issues can all be related to the topic of corporate governance.

Corporate governance is a very broad and complex area, especially when you are dealing with family businesses. The discussions on corporate governance usually cover the issues of control and interest differences between the owners and the management and seek ways to align the interests of both sides [59]. Presently, academics and professionals have shown increasing interest in the study of corporate governance, which enhances our knowledge of how corporate governance influences firm's management, strategies and performance. By definition, corporate governance may be seen as the system by which companies are directed and controlled [58]. It centres on the configuration of control mechanisms that attempts to limit problems arising from potential con- 
flict of interest between the different participants in the firm, such as, managers, shareholders, employees, creditors, etc.

According to the revised principles of corporate governance of OECD, corporate governance can be defined as:

"Procedures and processes according to which an organization is directed and controlled. The corporate governance structure specifies the distribution of rights and responsibilities among the different participants in the organization-such as the board, managers, shareholders and other stakeholders-and lays down the rules and procedures for decision making.” [60].

Keasyey et al. and Blair describes this perception of corporate governance, which mainly refers to agency theory, as the so-called narrow-view [59]. In contrast to that there is the definition by Neubauer \& Lank [1] that sees corporate governance in a broader sense as, "a system of structures and processes to secure the economic viability as well as the legitimacy of the corporation. (...) economic viability means securing the long-term sustainable development of the firm.” Agency and Stewardship Theory are both common tools to investigate ownership and management in family businesses and understand family businesses performance and objectives [61]. Since most family businesses are characterised by a stewardship-oriented culture [62], there will be more emphasis on this concept within corporate governance.

Specifically, corporate governance is divisible into: corporate governance structure and corporate governance process. Governance structures, which include ownership structure and board structure, are intended to discipline the behaviour of corporate governance actors (owners, directors and executive management). Governance processes refer to the interaction of governance actors based on governance structures. Hence, governance structures influence the effectiveness of the governance process and ultimately the firm performance. Evidence from the literature suggests that good governance generates investor goodwill and confidence. For example, Gompers et al. [8] stated that, where there is good corporate governance it increases the firm's valuations and boosts the bottom line. Claessens et al. [63] also maintain that better corporate frameworks benefit firms through greater access to financing, lower cost of capital, better performance and more favourable treatment of all stakeholders. From these assertions therefore our hypothesis 1 is:

H1 = Good Corporate Governance Affects Performance of Family Businesses.

Corporate governance has dominated policy agenda in developed market economies for more than two decades, and it is gradually worming its way to the top of the policy agenda on the African continent. The Asian crisis and the relative poor performance of the corporate sector in sub-Saharan Africa have made corporate governance a catchphrase in the development debate [64].

Traditionally, corporate governance has been associated with larger companies and the existence of the agency problem. This agency problem arises as a result of the relationships between shareholders and managers. It comes about when members of an organization have conflicts of interest within the firm. This is mainly due to the separation between ownership and control of the firm. It is therefore tempting to believe that corporate governance would not apply to family businesses since the agency problems are less likely to exist. In many instances, family businesses are made up of only the owner who is the sole proprietor and manager [65]. Basically, family businesses tend to have a less pronounced separation of ownership and management than larger firms and they provide a better governance system. The second hypothesis for this study therefore becomes:

H2 = Family Businesses Have a Better Governance Systems than Non-Family Businesses

It has been identified by many writers that governance has a positive influence on a business's performance [66]-[69] and that poorly governed businesses are expected to be less profitable, have more bankruptcy risks, lower valuations and pay out less to their shareholders. Others argue that weak corporate governance does not only lead to poor firm performance and risky financing patterns, but are also conducive to macroeconomic crises.

The term "corporate governance" has been used in many different ways and the boundaries of the subject vary widely. Despite these the three key but divergent theories that underpin perceptions and approaches to corporate governance are "Agency Theory", "Stewardship Theory", and "Stakeholder Theory". Among these three theories, the one more peculiar to family business is the Stewardship Theory.

\section{Stewardship Theory}

Stewardship Theory has its roots from psychology and sociology and is defined by Davis, Schoorman \& 
Donaldson [70] as "a steward protects and maximizes shareholder wealth through firm performance, because by so doing, the steward's utility functions are maximized”. The approach adopted by this theory is that the board of directors and the chief executive officer, acting as stewards, are more motivated to act in the best interests of the corporation rather than for their own self-interest. The theory argues that over time senior executives tend to view the corporation as an extension of themselves [71]. Top management gives emphasis to the long term success of the corporation and not use the firm for their own needs. In short, the theory argues that top management care more about a company's long term success than the shareholders [72].

Due to this, it gives a better understanding of owner-manager relations within family businesses who also pursue non-financial goals [61]. As family businesses are characterised by very closely held ownership structures [73], it seems to be reasonable to go beyond control mechanisms to align or preserve the owners' interest towards the management, which would refer to the narrow-view. Hence, it is reasonable to take the broader view on corporate governance, which includes the long-term survivability of a firm, as this is also a dominant aspect of the overall strategy of family businesses [74] [75].

In this perspective, stewards are company executives and managers working for the shareholders, protect and make profits for the shareholders. Unlike Agency Theory, Stewardship Theory stresses not on the perspective of individualism [76], but rather on the role of top management being as stewards, integrating their goals as part of the organization. The stewardship perspective suggests that stewards are satisfied and motivated when organizational success is attained.

Agyris [77] argues that Agency Theory looks at an employee or people as an economic being, which suppresses an individual's own aspirations. However, Stewardship Theory recognizes the importance of structures that empower the steward and offers maximum autonomy built on trust. It stresses on the position of employees or executives to act more autonomously so that the shareholders' returns are maximized. Indeed, this can minimize the costs aimed at monitoring and controlling behaviours [76].

\section{Why Corporate Governance Is Crucial for Family Businesses}

Increasing growth and globalisation has brought many challenges for family businesses and many of these challenges can be tackled by adopting sound corporate governance structures [78]. As the family business expands, the relationship among the owners, managers and employees becomes more complex. To be able to handle such issues, a good corporate governance system put in place the right policies to manage such a complexity.

Corporate governance creates a solid organizational structure that clarifies roles, reporting lines and delegation of responsibility. It also draws the line between ownership and management and separate policy direction from the day-to-day running of the company. Also successful family businesses are the result of years of hard work and dedication and there is a need to ensure that the leadership transition does not disrupt the company's growth [79]. To pass on this success to the next generation, corporate governance needs to be made part of the family business culture so that there would be clear policies for the selection of the right family member to take over. It would also provide clear guidelines for employing family or non-family members and an impartial performance-based promotion of employees which is essential to the sustainability of the business.

A solid governance system helps to resolve conflicts within the family setting, thereby allowing the family members to focus on other key issues of the business. This would invariably lead to an open decision making and procedures that ensures fairness, an essential tool in avoiding tension and thereby raising the reputation of the company.

In line with the above, the following principles of corporate governance [80] must be adhered to in the family business:

- Shareholder recognition is a key to maintaining a company's stock price. More often than not, however, small shareholders with little impact on the stock price are brushed aside to make way for the interests of majority shareholders and the executive board. Good corporate governance seeks to make sure that all shareholders get a voice at general meetings and are allowed to participate.

- Stakeholder interests should also be recognized by corporate governance. In particular, taking the time to address non-shareholder stakeholders can help your company establish a positive relationship with the community and the press.

- Board responsibilities must be clearly outlined to majority shareholders. All board members must be on the same page and share a similar vision for the future of the company.

- Ethical behaviour violations in favour of higher profits can cause massive civil and legal problems down 
the road. Underpaying and abusing outsourced employees or skirting around lax environmental regulations can come back and bite the company hard if ignored. A code of conduct regarding ethical decisions should be established for all members of the board.

- Business transparency is the key to promoting shareholder trust. Financial records, earnings reports and forward guidance should all be clearly stated without exaggeration or "creative" accounting.

Good corporate governance therefore strengthens and clarifies the activities of the family business while improving its competitiveness. Proper functioning and transparency of the roles and responsibilities of all organs in the firm are in the interest of the owners, other stakeholders and the whole company.

It is particularly essential in family business that the roles and responsibilities of the distinct owners, operative executives and the family are clear and that they are jointly defined and approved. Family businesses also utilize the organs of corporate governance in a specific manner. In family businesses, jointly agreed corporate governance practices primarily act as concrete tools for developing and controlling business activities. For instance, the owners are aware of their various ownership roles and influence; the board of directors and the managing director have their own clearly defined roles and responsibilities, as do the council of owners. The clearly defined corporate governance of family business also creates added value to those activities with external stakeholders, for instance, in financial and investment processes.

\section{Governance in Family Business}

Governance is concerned with all of the ways that the interest of owners is reflected and implemented in the organizational system. The financial and economic crisis in 1997 shook many top family businesses in the world, leading to an erosion of their business base. The crisis wiped out some of the most prominent family business groups in the world. The crisis has generated a lot of interest. Many scholars have attempted to examine the causes as well as to search for ways to reform. One of the contributing factors is the poor corporate governance in the corporate sector, which is due to "ownership concentration". If the goal is long term continuity, this points to the need to institutionalize the roles and relationships that are present in the family business, rather than simply rely on current relationships. In short, long term business continuity requires there to be clarity as to how the family business will be governed.

All family governance structures and institutions require a certain degree of formalization if they are to function well. When these families adopt policies on the family's approach to the business and for governing the business, they will formalize these efforts with documents that will differ depending on their ownership stage of the business. Normally, in the earlier stages when the company is governed by the founder or his/her children, many aspects of family and business governance are informal. Efforts to formalize will mostly relate to the business itself.

The family aspect is what differentiates family businesses from their counterpart non-family businesses. As a consequence, the family plays a crucial role in the governance of these businesses. When the family is still at its initial founder(s) stage, very few family governance issues may be apparent as most decisions are taken by the founder(s) and the family voice will be still unified. Over time, as the family goes through the next stages of its lifecycle, newer generations and more members join the family business. This implies different ideas and opinions on how the business should be run and how its strategies are set. It becomes mandatory, then a clear family governance structure that will bring discipline among family members, prevent potential conflicts, and ensure the continuity of the family's business should be established. A well-functioning family governance structure will mainly aim at:

- Communicating the family values, mission, and long term vision to all family members.

- Keeping family members (especially those who are not involved in the business) informed about major business accomplishments, challenges, and strategic directions.

- Communicating the rules and decisions that might affect family members' employment, dividends, and other benefits they usually get from the business.

- Establishing formal communication channels that allow family members to share their ideas, aspirations and issues.

- Allowing the family to come together and make any necessary decisions.

Developing such a governance structure will help build trust among family members (especially between those inside and outside of the business), and unify the family thus increasing the viability chances of the family business. 
First attempts at written policies usually are brief documents that state a general family vision and mission with respect to the company. The next level of formalization comes with the need to develop a family employment policies, which becomes more apparent when the company reaches the sibling partnership stage. The policy sets clear rules on terms and conditions of family employment within the firm. For some families, these rules stipulate conditions of entry, retention and exit from the business. It should also cover the treatment of family member employees' vis-à-vis non-family employees.

In their third, fourth and succeeding generations, family businesses can barely survive unless full family governance policies are developed, written and communicated within the family and the business, and also to other outside stakeholders. This document covering all of these policies is commonly called a family constitution. The document expresses the family's principles regarding the family commitment to core values, vision, and mission of the family's business. It often defines the roles, compositions, and functions of family governance institutions and the company's own governance bodies, such as the shareholders' meeting, the board of directors and senior management.

Governance in a family business can be thought of in terms of:

a) Structures, such as creating a family learning and development committee;

b) Processes, for example, creating and running ongoing ownership education programs and the annual preparation of a personal development plan; and

c) Policies, for example, an aspect of the family employment policy could be that family member employees are expected to participate in the family learning and development programs.

If the need of one domain has no way to be represented, they do not just evaporate, they find another outlet. This is like the displacement of an emotion. For example, if there is no way for ownership issues to be expressed they appear in the bad and board meetings turn into shareholders meetings ${ }^{1}$. This points to the importance of having appropriate structures and forums so that the interest of the family circle and the interests of ownership can be properly expressed. An example of this would be the creation of a "family council" or of an "owner's council". Basic governance structures in a family business can therefore include:

(i) a family assembly;

(ii) a family council;

(iii) a separate ownership council or forum;

(iv) the board of directors; and

(v) an advisory board.

From there a particular family might decide that it also needs one or more committees as depicted in Figure 1 below, for example a career planning committee. A simple diagram reflecting a basic governance structure for a family business could be as in Figure 1.

In looking at the definitions of what a family is, the concept implies certain links based on relationships of trust. This reduces the costs of running the enterprise because it lowers the costs of supervision while providing a safeguard against opportunist behaviour and may form the basis of moral integrity [81]. Trust may provide a competitive advantage to organizations that base their governance mechanisms on it [82]-[84]. However, the evolution of family businesses and the accompanying changes in the relationships of those involved in the different sub-systems may damage that trust. Thus, succession in the form of a sibling partnership or a cousin consortium will be linked to changes in the patterns of interrelationships in the families, which may weaken trust and make it necessary to invest in governance mechanisms in the family area in order to strengthen it [84]-[86].

In the light of the above, it is therefore necessary in family businesses to examine, apart from the elements of corporate governance, the role of the owner family in firm governance since it is precisely that family element that differentiates these organizations from any other business form. Family governance can therefore be defined as the set of institutions and mechanisms whose aim is to order the relationships occurring within the family context and between the family and the business. These mechanisms may be both formal and informal and will vary over time in line with stage of ownership and the life cycle of the firm and the family [1] [86] [87]. As the family passes through the evolutionary stages these family governance matures into a more formal system through the application of corporate governances principles.

\section{Methodology}

Qualitative research seeks to explore a specific phenomenon, not to prove a prediction. From a methodological

${ }^{1}$ Getting Along in Family Business: The Relationship Intelligence Handbook, Hoover \& Hoover. 


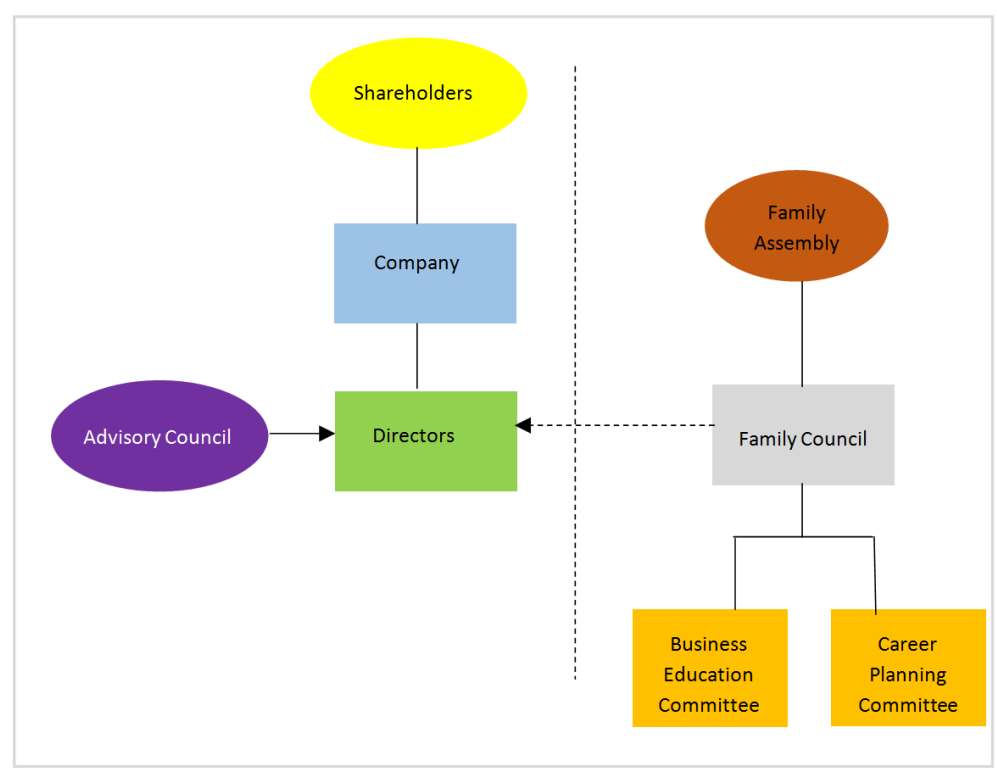

Figure 1. Family governance structure. Source: "Advising the family business: A guide for professionals”, David Bork, Dennis Jaffe, Sam Lane, Leslie Dashew, and Quentin Heisler, Jossey Bass.

www.familylegacyasia.com.

point of view, therefore, this paper will follow a qualitative approach. As Kontinen and Ojala [88] mention in their literature review about the state of the art in the field of the internationalization of family business, there is a need for case studies focusing on the questions of how and why companies make decisions and act in a certain way. It is recognized that previous studies have greatly emphasized quantitative research methods with a focus on positivistic measures, in order to evaluate the internationalization of family businesses from a scientific point of view [88] [89]. This spurred the present researcher to conduct qualitative research, which will allow a more in-depth investigation on a micro level.

Case study research involves an in-depth study of an individual or group of individuals. Case studies often lead to testable hypotheses and allow us to study rare phenomena. Case studies should not be used to determine cause and effect, and they have limited use for making accurate predictions. There are, however, two serious problems with case studies - expectancy effects and atypical individuals. Expectancy effects include the experimenter's underlying biases that might affect the actions taken while conducting research. These biases can lead to misrepresenting participants' descriptions. Describing atypical individuals may lead to poor generalizations and detract from external validity.

According to Holme \& Solvang [90], the qualitative approach is generally referred as being descriptive. This implies that the findings are described with the help of an interpretation process, which investigates the linked activities, experiences, believes and values in the case [90]-[92]. In most cases the qualitative approach serves to enhance understanding of the area of research. Furthermore, it is also often applied when there is a lack of theories in the specific area of interest [93]. Qualitative data is useful since it describes and captures the situation and emotions of the interviewees [94], while the quantitative method rather focuses on the facts, testing and verification [95].

Since the purpose of this research is to establish whether good corporate governance structures in family businesses is a must, a qualitative approach seems to be the most suitable one. This way, new knowledge can be gained and an understanding will be deepened, as the interviewees can show how they think about corporate governance structures in their businesses.

Two main approaches were used to achieve the purpose of the study. The first was the short personal interview during a familiarity visits to the selected family businesses. Based on the familiarity visit, interview format and a questionnaire was designed, which were used as a second approach in collecting responses from these family businesses. The questions were structured in such a way to provide information on family governance structures and corporate governance institutions in the business and how vital these are to the conduct of their 
businesses.

A purposive sampling technique was used to select one hundred and twenty (120) family businesses located in various parts of Ghana. Purposive method was used because these businesses are scattered all over the country. After the interviews' conclusions were drawn from the information obtained using a statistical package, the analysis were made.

\section{Analysis and Results}

The Bartlett's test of sphericity is used to test for the adequacy of the correlation matrix, i.e., the correlation matrix has significant correlations among at least some of the variables. If the variables are independent, the observed correlation matrix is expected to have small off-diagonal coefficients. Bartlett's test of sphericity tests the hypothesis that the correlation matrix is an identity matrix, that is, all the diagonal terms are 1 and all off-diagonal terms are 0 . If the test value is large and the significance level is small $(\mathrm{p}<0.05)$, the hypothesis that the variables are independent can be rejected. In the present analysis, the Bartlett's test of sphericity, as shown in Table 1, yielded a value of 14898.633 and an associated level of significance smaller than $0.000(\mathrm{p}<0.05)$. Thus, the hypothesis that the correlation matrix is an identity matrix is rejected.

The communalities output presents the communality of each variable (i.e., the proportion of variance in each variable accounted for by the common factors). Since the principal components method of factor extraction was used, as many factors as possible were computed as there are variables. When all factors were included in the solution, all of the variance of each variable was accounted for by the common factors. Thus, the proportion of variance accounted for by the common factors, or the communality of a variable is 1 for all the variables.

In Table 2, the total variance explained presents the number of common factors computed, the eigenvalues associated with these factors, the percentage of total variance accounted for by each factor, and the cumulative percentage of total variance accounted for by the factors. Although twenty factors have been computed, it is obvious that not all twenty factors will be useful in representing the list of twenty variables. In deciding how many factors to extract to represent the data, it is helpful to examine the eigenvalues associated with the factors. Since fifty-two (52) variables were considered for this study, the criterion of retaining only factors with eigenvalues of 1 or greater was used and the first four factors were retained for rotation. These four factors account for $77.484 \%, 9.964 \%, 3.835 \%$, and $2.269 \%$ of the total variance, respectively. That is, almost $93.551 \%$ of the total variance is attributable to these four factors. The remaining forty eight (48) factors together account for only approximately $6.449 \%$ of the variance. Thus, a model with four factors may be adequate to represent the data.

The pattern matrix shows the loadings of each of the variables. This shows the variable loadings on the four (4) factors with forty five (45) variables loading more than 0.35 on component 1 , eight (8) variables loading on component 2, six (6) variables loading on components 3 and 4 respectively. Now critically looking through the

Table 1. KMO and Bartlett’S Test.

\begin{tabular}{cccc}
\hline \multirow{2}{*}{ Kaiser-Meyer-Olkin Measure of Sampling Adequacy } & \multicolumn{3}{c}{ Bartlett's Test of Sphericity } \\
\cline { 2 - 4 } & Approx. Chi-Square & df & Sig. \\
\hline 0.957 & 27324.257 & 1326 & 0.000 \\
\hline
\end{tabular}

Source: Fieldwork.

Table 2. Total variance explained.

\begin{tabular}{ccccccc}
\hline \multirow{2}{*}{ Component } & \multicolumn{3}{c}{ Initial Eigenvalues } & \multicolumn{2}{c}{ Extraction Sums of Squared Loadings } \\
\cline { 2 - 6 } & Total & \% of Variance & Cumulative \% & Total & \% of Variance & Cumulative \% \\
\hline 1 & 40.292 & 77.484 & 77.484 & 40.292 & 77.484 \\
2 & 5.181 & 9.964 & 87.448 & 5.181 & 9.964 & 3.835 \\
3 & 1.994 & 3.835 & 91.282 & 1.994 & 91.282 \\
4 & 1.180 & 2.269 & 93.551 & 1.180 & 2.269 \\
\hline
\end{tabular}

Source: Fieldwork. 
matrix for the highest loading variables on each component to identify and label the component. Here, the main loadings on component 1 are variables: Shareholders are provided with sufficient company information, I am aware that I carry legal risk, I am aware of the level of remuneration of senior management in the business, the development of governance measures have kept up with the growth of the business, and suitable performance management systems are in place for the board, the contribution of the board is effective with loadings 1.010, $0.989,0.988,0.985,0.978$ and 0.976 respectively.

However, the main loadings on component 2 are variables: Company has a definitive constitution with regards to its business interests and family members are provided with sufficient company information with loadings 0.789 and 0.750 respectively. Also, the main loadings on component 3 are variables: My performance is monitored and managed and the company has a well policies and guidelines that regulate all the perks and benefits that I receive with loadings 0.943 and 0.755 respectively. Further, component 4 had the main loadings as follows: You regard this as a family business and the company has other sister companies with loadings 0.397 and 0.337 respectively.

Thus the first component was identified as organization's corporate governance, the second component identified as the organization's family governance, the third component identified as the organization's executive management, the forth component identified as the organization's general.

From Table 3, executive management has about 0.811 correlations with the corporate governance of the family business. This indicates that there is a strong relationship between executive management and the corporate governance of the family business system. Thus executive management correlates positively with corporate governance and the correlation is significant at $p<0.01$. It can also be observed that 0.214 Spearman's rho correlation coefficient shows a weak positive relationship between family governance and corporate governance of the family business system. At $\mathrm{p}<0.01$, there is sufficient evidence to conclude that the correlation presence between family governance and corporate governance of the family business is significant.

\section{Discussion and Recommendations}

The purpose of this study was to investigate whether a corporate governance structure is a must for family businesses. The main question with respect to whether good corporate governance practises can lead to improved performance of family businesses or not. To answer this question, we derived two major research hypotheses, each focusing on a different aspect presented in the frame of reference. The aim of this study was therefore to contribute to the on-going debates in the field of family business corporate governance. With this paper we advance the understanding of how and why family businesses set up their governance structures and consequently contribute to an area where a lack of qualitative research exists.

The study proves that the issues of family business corporate governance come to the fore when the business owners consider major transitions such as the sale of the business or succession planning. It was realised that although informal governance in some family businesses seem to work well, there is still a need to have a more formal corporate governance structure to plan ahead for the business. In most cases, major undertakings and decisions are made as a family, with the head of the family taking the lead. But as the business grows, the need for a more formal framework was required in these businesses so as to avoid overlap, confusion and possible disagreement.

Table 3. Spearman's rho correlation coefficients.

\begin{tabular}{|c|c|c|c|c|c|}
\hline & & & Executive & Family & Corporate \\
\hline \multirow{6}{*}{ Spearman's rho } & \multirow{2}{*}{ Executive } & Correlation Coefficient & 1.000 & 0.148 & $0.811^{* *}$ \\
\hline & & Sig. (2-tailed) & 0. & 0.056 & 0.000 \\
\hline & \multirow{2}{*}{ Family } & Correlation Coefficient & 0.148 & 1.000 & $0.214^{* *}$ \\
\hline & & Sig. (2-tailed) & 0.056 & . & 0.005 \\
\hline & \multirow{2}{*}{ Corporate } & Correlation Coefficient & $0.811^{* *}$ & $0.214^{* *}$ & 1.000 \\
\hline & & Sig. (2-tailed) & 0.000 & 0.005 & . \\
\hline
\end{tabular}

\footnotetext{
${ }^{* *}$ Correlation is significant at the 0.01 level (2-tailed). Source: Fieldwork
} 
This study therefore proves the importance of a stewardship oriented culture and low agency cost for family businesses as a source of competitive advantage, which is based on informal governance structures. Indeed it is established that family businesses need a continuous communication culture, a transparent plan to follow and clear lines of authority. When they achieve this it helps to alleviate any problems within the family business due to emotions and confusion caused by the absence of it. It also comes out whilst that most family businesses recognise that governance structures are vital elements for their businesses, only a few manage to inculcate corporate governance into their systems and business structure.

It also came to light that the need for a governing board for family businesses is essential for the running of such businesses. A vibrant and effective board should be responsible for adding value to the business in three ways:

1) Presiding over the leadership, operations and finances of the business;

2) Ensuring that the business has a strategic direction by anticipating the need for change and identifying new opportunities for it;

3) Mediating among the needs of family shareholders, employees, other stakeholders and the business.

For any family business board to be effective, the members should include family owners/shareholders, executive directors (employees) and non-executive directors (non-employees), and the board is bound to act in good faith, care and due diligence as they are appointed to look after the interests of the organization and its employees.

In conclusion it must be stated that the principles of corporate governance apply to both listed and non-listed companies and institutions in the private and public sectors in Ghana, such as non-governmental organizations, charities, businesses and government boards, trusts and agencies. Aside these, good governance is a must for every business but for family businesses, corporate governance is a crucial paradigm shift, so significant, that it determines the continuity or growth of every family business. The main goal of good corporate governance is to give direction for families in the business as they move on to the next stage of development of their businesses, and its consequences on the family and the business as a whole.

However, at that stage of their development certain challenges unique to family businesses, such as business succession and exit planning, can be critical to the success of the business. Therefore to address family business issues, the governing boards serve as a working resource to lay down sound decisions on strategy, accountability, succession and responsibility. In view of that, attaining certain level of reflective capability, expertise, knowledge and power by the board to bind the family and the business, especially during difficult times, is needed to empower them to make the best business decisions. Indeed, family businesses maintain and play a key role in Ghanaian business community, as well as contribute immensely towards the economic development of the country. Ensuring their continuity therefore by bringing matters to the corporate table has great potential to build not only stronger family businesses, but also stronger families as well.

The need to minimize corruption in the Ghanaian business and corporate sector is inevitable and this calls for government interventions in the form of legislations to establish strict governance structures at all levels. This is necessary because large family businesses in developed countries that survive for many generations make sure to permeate their ethos of ownership with a strong sense of purpose. They indeed develop oral and written agreements over time that address issues such as the composition and election of the company's board, the key board decisions that require a consensus or a qualified majority, the appointment of the chief executive officer, the conditions in which family members can (and cannot) work in the business, and some of the boundaries for corporate and financial strategy.

It is also recognized that keeping a business going across generations is hard. However, the failure to maintain the family business can come from a number of causes. This may include divisions formed between those relatives enjoying both salaries and dividends and those receiving only dividends, which may create jealousy among some family employees who rise higher than others or work less hard for the same pay. Further for some businesses supervisors, they may even find themselves incapable of firing an under-performing subordinate who is a child, a sibling or a cousin. Also as the business grows and markets evolve, finding sufficient managerial talent and experience within the family becomes harder and when the family decides at last to hire an outside manager, failure to motivate and monitor him can damage or destroy the established family business. In order to solve some of these problems in family businesses, corporate governance goes to the heart of them, though many family-run businesses have never thought of it in these terms. Family owners need corporate governance both to operate the business and to promote family harmony. It may involve putting in place decision-making and moni- 
toring procedures that are open and fair, as well as possibly hiring non-family members as advisors, managers and directors. This is not an overnight exercise, however, it can help businesses represent the work and the wealth of several generations and also help business owners to preserve, enlarge and pass on this legacy to the next generation. However, they can achieve this only by making corporate governance a family affair.

Family businesses who want to survive in these turbulent economies must develop agreements that will superintend over their governance decisions. In order to this, the continual development and interpretation of these agreements, and the governance decisions guided by them, may involve several kinds of family forums. A family council representing different branches and generations of the family, for instance, may be responsible to a larger family assembly used to build consensus on major issues.

The study showed that most family businesses often worry that family governance means introducing needless complexity and bureaucracy into their business. However, the relevance of corporate governance cannot be over emphasized since it constitutes the organizational climate for the internal activities of a company. In Ghana, corporate governance can greatly assist the family businesses by infusing better management practices, stronger internal auditing and greater opportunities for growth. Good corporate governance structures encourage families to communicate and work together more effectively, and it is pivotal to the success of any family business.

By adopting corporate governance measures at both the family and business levels, it provides good solutions to family ownership challenges and such measures are indispensable to the long-term successes of the family business. Corporate governance brings new strategic outlook through external independent directors; it enhances a firms' corporate entrepreneurship and competitiveness. It is not a threat to value creation in entrepreneurial firms if the guidelines on corporate governance are properly applied.

In the course of running such businesses, family-owned businesses face many challenges for their profitability. Also another set of challenges they face which need to address is how to obtain the trust of investors and, in many cases, to make the company sustainable in the long run. Good governance mechanisms among family businesses are likely to result in boards exerting much needed pressure for improved performance by ensuring that the interests of the firms are served.

Furthermore, increasing growth and globalisation have brought many challenges for family businesses and the way to deal with these issues could mean the difference between success and failure. However, many of these challenges can be tackled by adopting sound corporate governance structures. It must be stated that good governance practices make all the difference for a family-owned company. Family businesses with effective governance policies, procedures and practices are more likely to carry out effective strategic and succession planning.

With effective strategic planning, board members bring into the firm expertise and knowledge on financing options available and strategies to source such finances thus dealing with the credit constraint problem of family businesses as well. Often businesses that seeking new funds find that they have much work to do before confidently going to the market. A consistent track record of good governance will greatly assist when that point comes. It must be noted that good governance does not guarantee business success. However, poor governance could be symptomatic of a business failure. More importantly, lifting the confidence of existing owners and potential new ones is a valuable goal.

With growth of the family business, a call for a possible sale of the firm may arrive and during this period corporate governance becomes crucial to the organization. Where a firm consistently practices good governance will greatly assist when that point comes. Thus the transition from a small to medium and finally large company will be smoothly aided by an effective corporate control system.

Finally, applying good governance principles will reduce the problems associated with information asymmetry and makes the family less risky to invest in since corporate governance has been accepted globally as a system of law and sound approaches by which corporations are directed and controlled, focusing on the internal and external structures with the intention of monitoring the actions of management and directors, so as to mitigate agency risks that may stem from the misdeeds of corporate officers.

However, the corporate governance measures that family businesses can adopt will vary, depending on the stage of the controlling family's ownership, but in doing this attention should also be drawn to the disadvantages of corporate governance. These may include additional roles in audit, remuneration and nomination committees, new and more directors to be hired, especially non-executive directors who will also have to be paid higher remuneration because of active roles they will play. These and others may lead to increase operational costs but nonetheless, the benefits of corporate governance in family businesses for an economy like Ghana cannot be overlooked. 


\section{References}

[1] Neubauer, F. and Lank, A. (1998) The Family Business: Its Governance for Sustainability. MacMillan Press Ltd., Houndmills, 65-67.

[2] Sarbah, A. and Xiao, W. (2013) Corporate Governance Practices in Ghanaian Family Businesses: A Conceptual Framework. International Journal of Advancements in Research \& Technology, 3, 100-115.

[3] The Pearl Initiative \& PricewaterhouseCoopers (2012) Family Matters Governance Practices in GCC Family Firms. http://www.pwc.com/en_M1/m1/publications/documents/pipwc-report.pdf

[4] Ward, J.L. (1991) Creating Effective Boards for Private Enterprises: Meeting the Challenges of Continuity and Competition. Jossey-Bass, San Francisco.

[5] Litz, R.A. (1995) The Family Business: Toward Definitional Clarity. Family Business Review, 8, 71-81. http://dx.doi.org/10.1111/j.1741-6248.1995.00071.x

[6] Poutziouris, P., O’Sullivan, K. and Nicolescu, L. (1997) The [Re]-Generation of Family-Business Entrepreneurship in the Balkans. Family Business Review, 10, 239-261. http://dx.doi.org/10.1111/j.1741-6248.1997.00239.x

[7] Fahed-Sreih, J. (2009) An Exploratory Study on a New Corporate Governance Mechanism: Evidence from Small Family Firms. Management Research News, 32, 50-61. http://dx.doi.org/10.1108/01409170910922023

[8] Gompers, P.A., Ishii, J.L. and Metrick, A. (2003) Corporate Governance and Equity Prices. The Quarterly Journal of Economics, 118, 107-156. http://dx.doi.org/10.1162/00335530360535162

[9] Hua, J.Y., Miesing, P. and Li, M.F. (2006) An Empirical Taxonomy of SOE Governance in Transitional China. Journal of Management \& Governance, 10, 401-433. http://dx.doi.org/10.1007/s10997-006-9008-Z

[10] Lubatkin, M.H., Schulze, W.S., Ling, Y. and Dino, R.N. (2005) The Effects of Parental Altruism on the Governance of Family-Managed Firms. Journal of Organizational Behaviour, 26, 313-330. http://dx.doi.org/10.1002/job.307

[11] Carney, M. and Gedajlovic, E. (2001) Corporate Governance and Firm Capabilities: A Comparison of Managerial, Alliance and Personal Capitalism. Asia Pacific Journal of Management, 18, 335-354. http://dx.doi.org/10.1023/A:1010649828352

[12] Morck, R., Shleifer, A. and Vishny, R.W. (1988) Management Ownership and Market Valuation. Journal of Financial Economics, 20, 293-315. http://dx.doi.org/10.1016/0304-405X(88)90048-7

[13] Emmons, W.R. and Schmid, F.A. (1999) Corporate Governance and Corporate Performance. Working Paper 1999018A, Federal Reserve Bank of St. Louis, St. Louis. http://research.stlouisfed.org/wp/1999/99-018.pdf

[14] Severin, E. (2001) Ownership Structure and the Performance of Firms: Evidence from France. European Journal of Economic and Social Systems, 15, 85-107.

[15] Drobetz, W., Schillhofer, A. and Zimmermann, H. (2004) Corporate Governance and Expected Stock Returns: Evidence from Germany. European Financial Management, 10, 267-293. http://dx.doi.org/10.1111/j.1354-7798.2004.00250.x

[16] Klapper, L.F. and Love, I. (2004) Corporate Governance, Investor Protection and Performance in Emerging Markets. Journal of Corporate Finance, 10, 703-728. http://dx.doi.org/10.1016/S0929-1199(03)00046-4

[17] Brown, L.D. and Caylor, M.L. (2006) Corporate Governance and Firm Operating Performance. http://ssrn.com/abstract $=814205$

[18] Bistrova, J. and Lace, N. (2011) Evaluation of Corporate Governance Influence on Stock Performance of CEE Companies. Proceedings of the 2011 WMSCI, Orlando, 19-22 July 2011, 59-64. http://www.iiis.org/CDs2011/CD2011SCI/SCI_2011/PapersPdf/SA110RC.pdf

[19] Walls, J.L., Berrone, P. and Phan, P.H. (2012) Corporate Governance and Environmental Performance: Is There Really a Link? Strategic Management Journal, 33, 885-913. http://dx.doi.org/10.1002/smj.1952

[20] Milgrom, P. and Roberts, J. (1992) Economics, Organization \& Management. Prentice Hall, New York.

[21] Cadbury, S.A. (1999) Sir, What Are the Trends in Corporate Governance? How Will They Impact Your Company? Long Range Planning, 32, 12-19.

[22] Abor, J. and Quartey, P. (2010) Issues in SME Development in Ghana and South Africa. International Research Journal of Finance and Economics, 39, 218-228.

[23] Millinuex, A.W. (1997) The Funding of Non-Financial Corporations (NFCs) in the EU (1971-1993): Evidence of Convergence. Mimeo, Department of Economics, University of Birmingham, Birmingham.

[24] Peters, M. (2005) Succession in Tourism Family Business: The Motivation of Succeeding Family Members. Tourism Review, 60, 12-18. http://dx.doi.org/10.1108/eb058461

[25] Garcia-Castro, R. and Casasola, M.J. (2011) A Set-Theoretic Analysis of the Components of Family Involvement in 
Publicly Listed and Major Unlisted Firm. Journal of Family Business Strategy, 2, 15-25. http://dx.doi.org/10.1016/j.jfbs.2011.01.002

[26] Astrachan, J.H. and Shanker, M.C. (2003) Family Businesses’ Contribution to the US Economy: A Closer Look. Family Business Review, 16, 211-219.

[27] Chua, J.H., Chrisman, J.J. and Sharma, P. (1999) Defining the Family Business by Behaviour. Entrepreneurship Theory and Practice, 23, 19-39.

[28] Lansberg, I.S., Perrow, E.L. and Rogolski, S. (1988) Family Business as an Emerging Field. Family Business Review, 1, 1-8. http://dx.doi.org/10.1111/j.1741-6248.1988.00001.x

[29] Habbershon, T. and Williamson, M.L. (1999) A Resource Based Framework for Assessing the Strategic Advantages of Family Firms. No. 39, Enterprising Families Initiative, The Wharton School, Philadelphia.

[30] Donckels, R. and Fröhlich, E. (1991) Are Family Businesses Really Different? European Experiences from STRATOS. Family Business Review, 4, 149-160. http://dx.doi.org/10.1111/j.1741-6248.1991.00149.x

[31] Barry, B. (1989) The Development of Organization Structure in the Family Firm. Family Business Review, 2, $293-315$. http://dx.doi.org/10.1111/j.1741-6248.1989.00293.x

[32] Handler, W.C. (1989) Methodological Issues and Considerations in Studying Family Businesses. Family Business Review, 2, 257-276. http://dx.doi.org/10.1111/j.1741-6248.1989.00257.x

[33] Donnelly, R.G. (1964) The Family Business. Harvard Business Review, 42, 93-105.

[34] Ward, J.L. (1998) Professor of Private Enterprise. In: Neubauer, F. and Lank, A.G., Eds., The Family Business—Its Governance for Sustainability, Routledge, London.

[35] Ward, J.L. and Aronoff, C.E. (1990) To Sell or Not Sell. Nations Business, 78, 63-64.

[36] Kircho, B.A. and Kircho, J.J. (1987) Family Contributions to Productivity and Profitability in Small Business. Journal of Small Business Management, 25, 25-31.

[37] Pearson, A.W., Carr, J.C. and Shaw, J.C. (2008) Towards a Theory of Familiness: A Social Capital Perspective. Entrepreneurship Theory and Practice, 32, 949-969. http://dx.doi.org/10.1111/j.1540-6520.2008.00265.x

[38] Krappe, A., Goutas, L. and Schlippe, A. (2011) The Family Business Brand: An Enquiry into the Construction of the Image of Family Business. Journal of Political Economy, 1, 37-46.

[39] Melin, L. and Nordqvist, M. (2000) Corporate Governance Processes in Family Firms. The Role of Influential Actors and the Strategic Arena. Proceedings of ICSB World Conference 2000, Brisbane, 7-10 June 2000.

[40] Anderson, R. and Reeb, D. (2003) Founding-Family Ownership and Firm Performance: Evidence from S\&P 500. Journal of Finance, 58, 1301-1327. http://dx.doi.org/10.1111/1540-6261.00567

[41] Gallo, M.A. (1995) The Role of Family Business and Its Distinctive Characteristic Behavior in Industrial Activity. Family Business Review, 8, 83-97. http://dx.doi.org/10.1111/j.1741-6248.1995.00083.x

[42] McConaughy, D. and Phillips, G. (1999) Founders versus Descendants: The Profitability, Efficiency, Growth Characteristics and Financing in Large, Public, Founding-Family-Controlled Firms. Family Business Review, 12, $123-131$. http://dx.doi.org/10.1111/j.1741-6248.1999.00123.x

[43] Westhead, P. and Cowling, M. (1998) Family Business Research: The Need for a Methodological Rethink. Entrepreneurship: Theory and Practice, 23, 31-57.

[44] Peng, M.W. and Jiang, Y. (2010) Institutions behind Family Ownership and Control in Large Firms. Journal of Management Studies, 47, 253-273. http://dx.doi.org/10.1111/j.1467-6486.2009.00890.x

[45] Yu, T.F.L. (2001) The Chinese Family Business as a Strategic System: An Evolutionary Perspective. International Journal of Entrepreneurial Behaviour \& Research, 7, 22-28. http://dx.doi.org/10.1108/13552550110385736

[46] Iyer, G.R. (1999) The Impact of Religion and Reputation in the Organization of Indian Merchant Communities. The Journal of Business \& Industrial Marketing, 14, 102-117. http://dx.doi.org/10.1108/08858629910258982

[47] Aryeetey, E. (2001) Priority Research Issues Relating to Regulation and Competition in Ghana. Working Paper Series, Centre on Regulation and Competition, Manchester.

[48] Steel, W.F. and Webster, L.M. (1991) Small Enterprises in Ghana: Responses to Adjustment. Industry Series Paper No. 33, The World Bank Industry and Energy Department, Washington DC.

[49] Kayanula, D. and Quartey, P. (2000) The Policy Environment for Promoting Small and Medium-Sized Enterprises in Ghana and Malawi. Institute for Development Policy and Management, University of Manchester, Finance and Development Working Paper No. 15.

[50] Caspar, C., Dias, A.K. and Elstrodt, H. (2010) The Five Attributes of Enduring Family Businesses. Mckinsey Quarterly, January 2010.

[51] Lin, W. (2012) Family Ownership and Internationalization Processes: Internationalization Pace, Internationalization 
Scope, and Internationalization Rhythm. European Management Journal, 30, 47-56. http://dx.doi.org/10.1016/j.emj.2011.10.003

[52] Heck, R.K.Z. and Trent, E.S. (1999) The Prevalence of Family Business from a Household Sample. Family Business Review, 12, 209-224. http://dx.doi.org/10.1111/j.1741-6248.1999.00209.x

[53] Grant, R. (2006) The Family Business. CA Magazine, 139, 51-52.

[54] Claver, E., Rienda, L. and Quer, D. (2007) The Internationalisation Process in Family Firms: Choice of Market Entry Strategies. Journal of General Management, 33, 1-14.

[55] Abdellatif, M., Amann, M. and Jaussaud, J. (2009) Family versus Non-Family Business: A Comparison of International Strategies. Journal of Family Business Strategy, 2, 108-116.

[56] Cadbury, A. (2000) Family Firms and Their Governance: Creating Tomorrow’s Company from Today's. http://rru.worldbank.org/Documents/PapersLinks/family firms.pdf

[57] Carsrud, A.L. (2006) Commentary: “Are We Family and Are We Treated as Family? Nonfamily Employees’ Perceptions of Justice in the Family Firm": It All Depends on Perceptions of Family, Fairness, Equity, and Justice. Entrepreneurship Theory and Practice, 30, 855-860. http://dx.doi.org/10.1111/j.1540-6520.2006.00156.x

[58] Astrachan, J.H. (2010) Strategy in Family Business: Toward a Multidimensional Research Agenda. Journal of Family Business Strategy, 1, 6-14. http://dx.doi.org/10.1016/j.jfbs.2010.02.001

[59] Eisenmann-Mittenzwei, A. (2006) Familienunternehmen und Corporate Governance: Themen eines Diskurses. Verlag Dr. Kovac, Hamburg.

[60] Organization for Economic Cooperation and Development, OECD (2005) Glossary of Statistical Terms. http://stats.oecd.org/glossary/detail.asp?ID=6778

[61] Westhead, P. and Howorth, C. (2006) Ownership and Management Issues Associated with Family Firm Performance and Company Objectives. Family Business Review, 19, 301-316. http://dx.doi.org/10.1111/j.1741-6248.2006.00077.x

[62] Miller, D. and Le Breton-Miller, I. (2005) Managing for the Long Run: Lessons in Competitive Advantage from Great Family Businesses. Harvard Business School Press, Boston.

[63] Claessens, S., Djankov, S., Fan, J.P.H. and Lang, L.H.P. (2002) Disentangling the Incentive and Entrenchment Effects of Large Shareholders. The Journal of Finance, 57, 2741-2771. http://dx.doi.org/10.1111/1540-6261.00511

[64] Berglöf, E. and Von Thadden, E.-L. (1999) The Changing Corporate Governance Paradigm: Implications for Transition and Developing Countries. Proceedings of the Annual World Bank Conference on Development Economics, Washington DC, 3-4 June 1999, 1-31. http://dx.doi.org/10.2139/ssrn.183708 http://ssrn.com/abstract=183708

[65] Hart, O. (1995) Corporate Governance: Some Theory and Implications. The Economic Journal, 105, 678-698. http://dx.doi.org/10.2307/2235027

[66] Bebchuk, L., Cohen, A. and Ferrell, A. (2004) What Matters in Corporate Governance and Control. NBER Working Papers, No. 9371, National Bureau of Economic Research, Inc., Cambridge.

[67] Kyereboah-Coleman, A. and Biekpe, N. (2006) The Link between Corporate Governance and Performance of the NonTraditional Export Sector: Evidence from Ghana. Corporate Governance, 6, 609-623. http://dx.doi.org/10.1108/14720700610706090

[68] Kyereboah-Coleman, A. and Biekpe, N. (2006) Do Boards and CEOs Matter for Bank Performance? A Comparative Analysis of Banks in Ghana. Journal of Corporate Ownership and Control, 4, 119-126.

[69] Kyereboah-Coleman, A. and Biekpe, N. (2006) Corporate Governance and Financing Choices of Firms: A Panel Data Analysis. South African Journal of Economics, 74, 670-681. http://dx.doi.org/10.1111/j.1813-6982.2006.00097.x

[70] Davis, J.H., Schoorman, D.L. and Donaldson, L. (1997) The Distinctiveness of Agency Theory and Stewardship Theory. Academy of Management Review, 22, 611-613.

[71] Clark, T. (2004) Theories of Corporate Governance: The Philosophical Foundations of Corporate Governance. Routledge, London and New York.

[72] Mallin, C.A. (2004) Corporate Governance. Oxford University Press, Oxford.

[73] Brunninge, O., Nordqvist, M. and Wiklund, J. (2007) Corporate Governance and Strategic Change in SMEs: The Effects of Ownership, Board Composition and Top Management Teams. Small Business Economics, 29, 295-308. http://dx.doi.org/10.1007/s11187-006-9021-2

[74] Kontinen, T. and Ojala, A. (2009) Internationalization of Family Firms: A Review of Extant Research. Journal of Family Business Strategy, 2, 97-107.

[75] Miller, D. and Le Breton-Miller, I. (2006) Family Governance and Firm Performance: Agency, Stewardship, and Capabilities. Family Business Review, 19, 73-87. http://dx.doi.org/10.1111/j.1741-6248.2006.00063.x

[76] Donaldson, L. and Davis, J. (1991) Stewardship Theory or Agency Theory: CEO Governance and Shareholder Returns. 
Academy of Management Review, 20, 65.

[77] Agyris, C. (1973) Some Limits of Rational Man Organizational Theory. Public Administration Review, 33, $253-267$. http://dx.doi.org/10.2307/974803

[78] Gulzar, M.A. and Wang, Z.J (2010) Corporate Governance and Non-Listed Family Owned Businesses: An Evidence from Pakistan. International Journal of Innovation, Management and Technology, 1, 127-128.

[79] Gatamah, K. (2008) Corporate Governance in the African Context. Centre for International Private Enterprise, Washington DC.

[80] Sun, L. (2014) Why Is Corporate Governance Important? WebFinance, Inc. http://www.businessdictionary.com/article/618/why-is-corporate-governance-important/

[81] Aronoff, C.E. and Ward, J.L. (1995) Family-Owned Businesses: A Thing of the Past or a Model for the Future? Family Business Review, 8, 121-130. http://dx.doi.org/10.1111/j.1741-6248.1995.00121.x

[82] Hosmer, L.T. (1995) Trust: The Connecting Link between Organizational Theory and Philosophical Ethics. Academy of Management Review, 20, 379-403.

[83] Cabrera-Suarez, K., De Saa-Perez, P. and Garcia-Almeida, D. (2001) The Succession Process from a Resource-and Knowledge-Based View of the Family Firm. Family Business Review, 14, 37-48. http://dx.doi.org/10.1111/j.1741-6248.2001.00037.x

[84] Steier, L. (2001) Family Firm, Plural Forms of Governance, and the Evolving Role of Trust. Family Business Review, 14, 353-368. http://dx.doi.org/10.1111/j.1741-6248.2001.00353.x

[85] Ward, J.L. (1987) Keeping the Family Business Healthy. Jossey-Bass, San Francisco.

[86] Gersick, K., Davis, J.A., Hampton, M.M. and Lansberg, I. (1997) Generation to Generation: Life Cycles of the Family Business. Harvard Business School Press, Boston.

[87] Carlock, R.S. and Ward, J.L. (2001) Strategic Planning for the Family Business Parallel Planning to Unify the Family and the Business. Palgrave, New York.

[88] Kontinen, T. and Ojala, A. (2010) Internationalization Pathways of Family SMEs: Psychic Distance as a Focal Point. Journal of Small Business and Enterprise Development, 17, 437-454. http://dx.doi.org/10.1108/14626001011068725

[89] Nordqvist, M., Hall, A. and Melin, L. (2009) Qualitative Research on Family Businesses: The Relevance and Usefulness of the Interpretive Approach. Journal of Management and Organization, 15, 294-308. http://dx.doi.org/10.5172/jmo.2009.15.3.294

[90] Holme, I.M. and Solvang, B.K. (1997) Forskningsmetodik, om kvalitativa och kvantitativa metoder. Studentlitteratur, Lund.

[91] Darlington, Y. and Scott, D. (2002) Qualitative Research in Practice. Open University Press, Berkshire.

[92] Yin, R.K. (2009) Case Study Research: Design and Methods. 4th Edition, SAGE Publications Ltd., Thousand Oaks.

[93] Merriam, S.B. (1998) Qualitative Research and Case Study Applications in Education. Jossey-Bass Publishers, San Francisco.

[94] Patton, M.Q. (2002) Qualitative Research and Evaluation Methods. 3rd Edition, Sage Publications Ltd., Thousand Oaks.

[95] Ghauri, P., Grønhaug, K. and Kristianslund, I. (1995) Research Methods in Business Studies: A Practical Guide. Prentice Hall, Hemel Hempstead. 
Scientific Research Publishing (SCIRP) is one of the largest Open Access journal publishers. It is currently publishing more than 200 open access, online, peer-reviewed journals covering a wide range of academic disciplines. SCIRP serves the worldwide academic communities and contributes to the progress and application of science with its publication.

Other selected journals from SCIRP are listed as below. Submit your manuscript to us via either submit@scirp.org or Online Submission Portal.
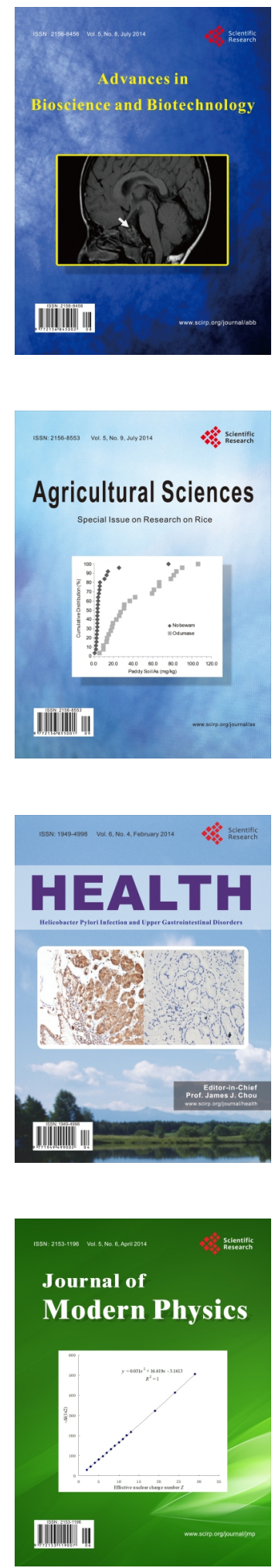
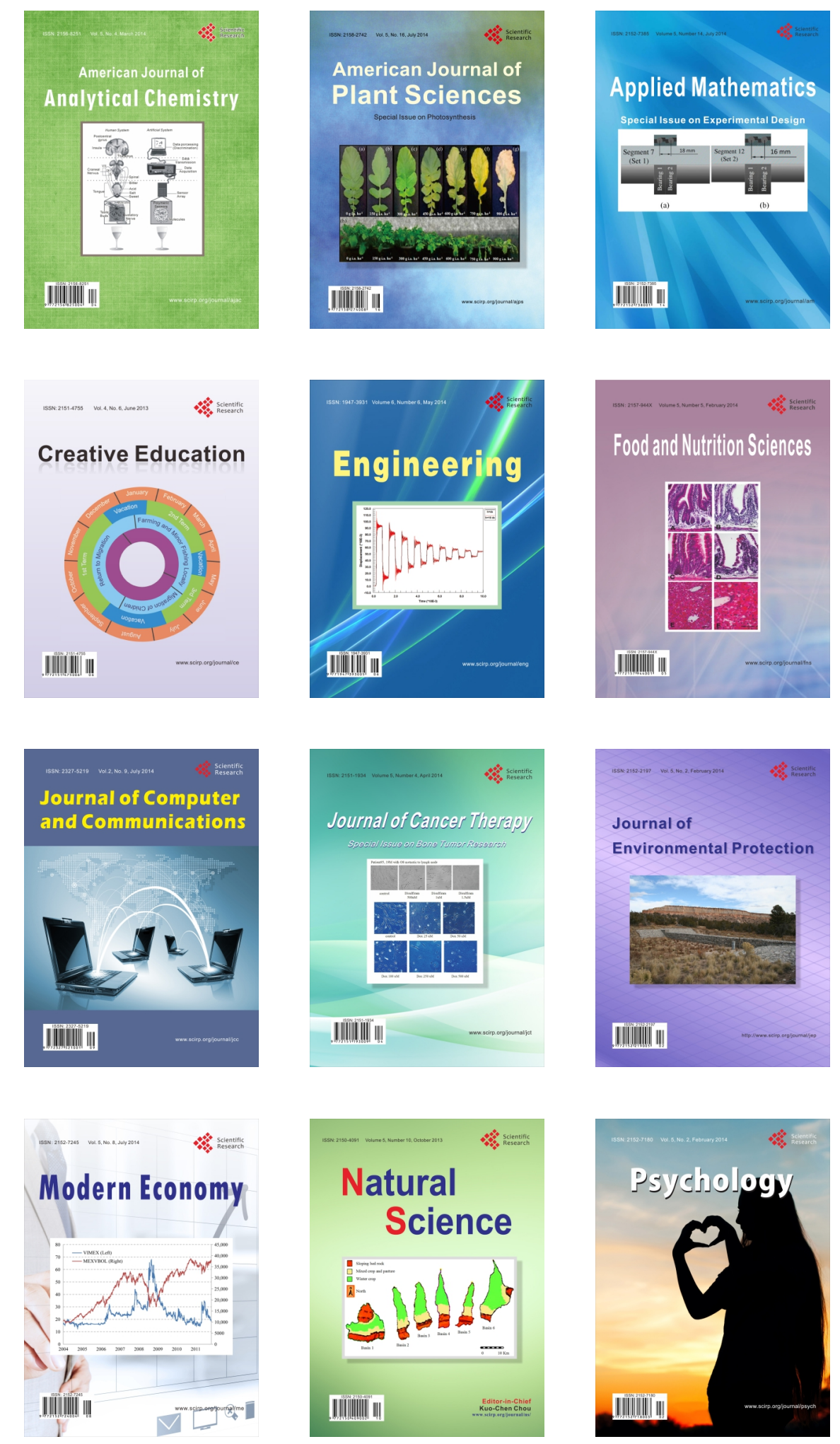